\section{EL DERECHO A LA CIUDAD DESDE LA ETNOGRAFÍA FEMINISTA: POLITIZAR EMOCIONES Y RESISTENCIAS EN EL ESPACIO URBANO}

Paula Pérez Sanz $z^{1}$

Carmen Gregorio Gil ${ }^{2}$

\section{Resumen}

Con este trabajo proponemos restituir el conocimiento que nos aporta una etnografía feminista sobre la producción de desigualdades de género y sexualidad en el espacio urbano, así como la contestación a éstas desde resistencias enmarcadas en la vida cotidiana. Partiendo de una revisión crítica de la noción del "Derecho a la Ciudad" nos preguntamos sobre el lugar que en ella ocupan las desigualdades de género y sexualidad. Seguidamente planteamos el valor de las emociones en su relación con el derecho a la ciudad y la etnografía como metodología apropiada para captar conflictos que tienen lugar en el espacio urbano y prácticas de resistencia

\section{THE RIGHT TO THE CITY FROM THE PERSPECTIVE OF FEMINIST ETHNOGRAPHY: POLITICIZING EMOTIONS AND RESISTANCE IN THE URBAN SPACE}

\author{
Paula Pérez Sanz \\ Carmen Gregorio Gil
}

\section{Abstract}

With this article we aim to restore the value of the knowledge provided by feminist ethnography about gender and sexual inequalities in the urban space, as well as issuing a response that addresses these inequalities from within resistances framed in everyday life. Starting from a critical review of the notion "Right to the city", we inquire about the place that gender and sexual inequalities have in this concept. Next, we underscore the value of emotions in relation to the right to the city, and ethnography as an appropriate methodology to register conflicts that take place in the urban space 
en la vida cotidiana. Para explicar nuestra propuesta nos apoyamos en diferentes trabajos que estudian el espacio urbano desde una perspectiva etnográfica. Dos son las emociones que encontramos inscritas en la reproducción de desigualdades de género y sexualidad a la hora de habitar la ciudad -las cuales también actúan como motor de resistencias cotidianas-: el "miedo" y la "no pertenencia". Nuestra indagación teórica y etnográfica nos lleva a presentar la etnografía feminista como una estrategia metodológica útil para ampliar la noción de derecho a la ciudad a la complejidad del conflicto urbano, más allá de la clase, así como para politizar estrategias de resistencia cotidianas, a menudo invisibilizadas.

PALABRAS CLAVE: ETNOGRAFÍA FEMINISTA, DERECHO A LA CIUDAD, EMOCIONES, GÉNERO Y SEXUALIDAD, VIDA COTIDIANA.

Recibido: 2019-09-27

Aceptado: 2020-05-11 and practices of resistance in everyday life. To explain our proposal, we draw on different works that study urban space from an ethnographic perspective. There are two emotions, "fear" and "non-belonging", that we find inscribed in the reproduction of gender and sexual inequalities in the daily experience of the city, and that would also act as a driver of daily resistances. Our theoretical and ethnographic research leads us to advance feminist ethnography as a useful methodological strategy to expand the notion of the right to the city to the complexity of urban conflicts, beyond class, as well as to politicize strategies of resistance in everyday life, too often made invisible.

\section{KEYWORDS: FEMINIST ETHNOGRAPHY, RIGHT TO THE CITY, EMOTIONS, GENDER AND SEXUALITY, DAILY LIFE.}

Received: 2019-09-27

Accepted: 2020-05-11
1 España. Doctoranda en Estudios de Mujeres y de Género en la Universidad de Granada http://orcid.org/0000-0002-7980-230X. Correo electrónico: paulaperezsanz@gmail.com
2 España. Profesora titular Universidad de Granada, http://orcid.org/0000-0003-3275-6016. Correo electrónico: carmengg@ugr.es 
"El conocimiento no puede separarse del mundo corporal de los sentimientos y las sensaciones; el conocimiento está ligado a lo que nos hace sudar, estremecernos, temblar,

todos esos sentimientos que se sienten, de manera crucial, en la superficie del cuerpo, la superficie de la piel con la que tocamos y nos toca el mundo"

Sarah Ahmed, La política cultural de las emociones

\section{Introducción: Etnografía feminista y el derecho a la ciudad}

Hacemos un alto en el camino que venimos recorriendo como doctoranda y directora de tesis para escribir juntas este texto con el que pretendemos valorar el conocimiento que nos aporta una etnografía feminista (Gregorio Gil, 2019) sobre la producción de desigualdades de género y sexualidad en el espacio urbano, así como la contestación a éstas desde resistencias enmarcadas en la vida cotidiana.

Para responder a esta cuestión, y siguiendo propuestas de la geografía y la antropología feminista, nos interrogamos a partir de la noción de "Derecho a la ciudad" planteada por Henri Lefebvre (1969) al objeto de pensar la forma en

3 A lo largo del texto citaremos la primera traducción al castellano de esta obra, aunque la edición original aparece en 1968 bajo el título Le droit allá ville.
"Knowledge cannot be separated from the bodily world of feeling and sensation; knowledge is bound up with what makes us sweat, shudder, tremble, all those feelings that are crucially felt on the bodily surface, the skin surface where we touch and are touched by the world"

Sarah Ahmed, The Cultural Politics of Emotions

\section{Introduction: Feminist Ethnography and the Right to the City}

We take a break in the road we've been walking as PhD candidate and thesis advisor to co-write this text with which we seek to appraise the insight that a feminist ethnography can provide us (Gregorio Gil, 2019) in regard to the production of inequalities of gender and sexuality in the urban space, as well as a way to respond to them from within resistances framed in everyday life.

To answer this question, and following proposals coming from feminist geography and anthropology, we direct our inquiry based on the notion of "Right to the city" as posed by Henri Lefebvre $(1969)^{3}$ to the purpose of thinking the

3 Throughout the text we shall quote from the first English translation of this work, although the original 1968 edition appears under the title Le droit à la Ville. 
que da cuenta del conflicto urbano y su posible validez para desvelar las desigualdades de género en su articulación con otras relaciones de poder.

Seguidamente, trataremos de explicar de qué forma la etnografía feminista, con su capacidad de atender a las subjetividades y a los sentidos cotidianos que adopta la ciudad, deviene en método valioso para mostrar el conflicto urbano desde sus dimensiones de género, sexualidad o raza, y no sólo en términos de clase. Concretamente, nos detendremos en el lugar que han tomado las emociones en diferentes trabajos etnográficos que se han centrado en la cuestión urbana y las relaciones de género como motores de generación de estrategias y prácticas de resistencia. Nos proponemos con ello politizar emociones y resistencias cotidianas que suelen quedar fuera de los llamados "movimientos sociales", concebidos como principales agentes de transformación urbana. Como venimos observando en nuestro contexto, son estos movimientos, así como el análisis de su práctica y discurso, los que en la última década han politizado el uso de la noción de Derecho a la ciudad, todo ello, en un marco de creciente restricción y penalización de los usos del espacio público mediante "políticas de vigilancia y control policial" (Cabrerizo, Sequera y Bachiller, 2016) o en oposición a su privatización como consecuencia de "políticas desarrollistas" y de "empresarialismo urbano" (Observatorio Metropolitano, 2014). way in which it provides an account of the urban conflict, and its validity in revealing the gender inequalities in their articulation with other relations of power.

Next, we shall attempt to explain in what way feminist ethnography, with its capacity to pay attention to the subjectivities and the everyday senses that the city embraces, becomes a valuable method in exposing the urban conflict from within its dimensions of gender, sexuality, or race, and not only in terms of class. Specifically, we shall examine the role that emotions have assumed in the different ethnographic works that have focused on the urban question and the relations of gender as drivers for the generation of strategies and practices of resistance. With this, we propose to politicize everyday emotions and resistances that tend to be left aside from the so-called "social movements", conceived as main agents of urban transformation. As we've been observing in our context lately, it is these movements, along with the studies on their practice and discourse, that have politicized the use of the notion Right to the city in the last decade, all this, within a scenario of growing restriction and penalization of the uses of public space by means of "policies of surveyance and police control" (Cabrerizo, Sequera and Bachiller, 2016) or opposing its privatization as consequence of "developmentalist policies" and "urban entrepreneurship" (Observatorio Metropolitano, 2014). 
Como ya apuntamos, nos situamos en la etnografía feminista, lo que, entre otras cuestiones, implica una crítica epistemológica al pensamiento androcéntrico y occidental, que opera desde la división entre razón y emoción y desprecia el valor de las emociones como fuente de conocimiento (Ahmed, 2014; Behar, 1996; Gregorio Gil, 2006, 2014, 2019; Okely, 1992). Sin entrar aquí en la discusión de si existe o no una etnografía feminista ${ }^{4}$, es indudable que la dicotomía razón/emoción ha permeado en la producción del conocimiento, reproduciendo una Ciencia androcéntrica, heterocentrada y etnocéntrica, tal y como han denunciado Flax (1987), Haraway (1995) o Harding y O’Barr (1987). Por su parte, la perspectiva feminista en antropología social desafió desde los inicios de la disciplina los pilares de una teoría etnográfica positivista y ajena a las emociones y las relaciones de poder que acontecen desde la intersubjetividad que implica nuestra presencia en el campo (Gregorio Gil, 2006). Desde este enfoque nos proponemos restituir y politizar las subjetividades en el proceso de producción de conocimiento, al tiempo que cuestionamos los imperativos del positivismo y la exigencia de objetividad como únicas vías posibles para producir conocimientos científicos y legítimos. Todo ello sustenta nuestra incomodidad por

4 Esta discusión ya fue planteada por Abu-Lughod (1990) en su trabajo que llevó por título "Can there be a feminist ethnography?" y compartimos con la autora que no solo es posible, sino que se viene realizando de muchas maneras posibles desde los orígenes de la disciplina (Gregorio, 2019).
As we already pointed out, we are situated in feminist ethnography, which, among other issues, implies an epistemological critique of the androcentric and Western thought that operates based on a division between reason and emotion and despises the value of emotions as source of knowledge (Ahmed, 2014; Behar, 1996; Gregorio Gil, 2006, 2014, 2019; Okely, 1992). Without entering here in the discussion about whether a feminist ethnography does actually exist ${ }^{4}$, there is no doubt that the dichotomy reason/emotion has permeated into the production of knowledge reproducing an androcentric, hetero-centered and ethnocentric science, just as Flax (1987), Haraway (1995) or Harding and O'Barr (1987) have denounced. The feminist perspective in social anthropology, on its part, has since the beginnings of the discipline challenged the pillars of positivist ethnographic theory, foreign to the emotions and power relations that occur within the intersubjectivity implicit in our being present in the field (Gregorio Gil, 2006). From this perspective, we propose to restore and politicize the subjectivities in the processes of production of knowledge, while at the same time questioning the imperatives of positivism and the demand for objectivity as only possible way of producing legitimate and scientific knowledge.

$4 \quad$ This discussion was already proposed by Abu-Lughod (1990) in his work entitled "Can there be a feminist ethnography?" and we share with the author that it is not only possible, but has been done in many different ways since the origins of the discipline (Gregorio, 2019). 
el androcentrismo presente en dichas formas de conocer la realidad social, nombrarla y reivindicarla. Desde este lugar epistemológico es desde el que deseamos traer algunas de las emociones que dan sentido a la acción humana al generar vínculos y participar en la construcción de identidades de género, sexualidad, clase y raza en el ejercicio del derecho a la ciudad.

Por otra parte, el espacio urbano ha sido centro de interés por razones de orden epistemológico y político. Como feministas, no deja de incomodarnos la revisitada noción de "derecho a la ciudad" de Lefebvre (1969) en los últimos años, pues aun resultándonos atractiva su idea de "derecho", nos preocupa que la prioridad que otorga al conflicto de clase nuble otras relaciones de poder que tienen lugar en el espacio urbano extrapolando a otros contextos un análisis centrado en la Francia de los años 60 del siglo XX. Es por ello que, como etnógrafas, tratamos de abrir nuevas vías metodológicas que nos permitan legitimar saberes, luchas cotidianas y maneras de ejercer el derecho a la ciudad, a menudo contextualizadas e invisibilizadas. Nos proponemos, por tanto, mostrar el valor que toman las emociones en nuestro quehacer etnográfico con relación a la problemática de las desigualdades que refleja y produce la ciudad, así como las formas de contestación y resistencia a las mismas.
All of this supports our discomfort with the anthropocentrism present in the said forms of knowing, naming, and reclaiming the social reality. From this epistemological place is where we want to bring back some of the emotions that have given sense to human action by generating links and by participating in the construction of identities of gender, sexuality, class, and race in the exercise of the right to the city.

On the other hand, urban space has been a focus of interest for epistemological and political reasons. As feminists, we can't but feel uncomfortable with the revisited notion of "right to the city" in Lefebvre (1969) of latter years for, even though we might find his notion of "right" attractive, we are concerned that the priority he gives to the class conflict may blur other relations of power that take place in the urban space, extrapolating to other contexts an analysis centered around France in the 20 $0^{\text {th }}$ Century 60s. That is why we, as ethnographers, try to open up new methodologic ways that allow us to legitimize knowledges, everyday struggles, and ways of exercising the right to the city, frequently contextualized and made invisible. We propose, therefore, to show the value that emotions have in our ethnographic work in relation to the problem of the inequalities that the city reflects and produces, as well as the forms of response and resistance to them. 
Somos conscientes del reto que implica esta propuesta, pues como ya han señalado algunos trabajos anteriores, el lugar de intersección entre el sujeto, sus emociones y la ciudad ha generado un espacio oscuro y poco investigado (Lindón, 2009, 2012). Aunque las emociones comienzan a adquirir un peso cada vez mayor dentro de la geografía y la antropología urbana (Aguilar y Soto, 2013; Bondi, Davidson y Smith, 2005; Enrique Rosas y Sánchez López, 2014; Lindón, Aguilar y Hiernaux, 2006), no podemos dejar de sentir una cierta sospecha hacia ese rincón inexplorado, pues en su existencia vemos una demostración de cómo la arquitectura o el urbanismo se han ido configurando desde presupuestos objetivistas y alejados de la experiencia concreta que las personas tienen de la ciudad. Nos inquieta cómo ese objetivismo podría llevarnos a obviar el hecho de que la ciudad se construye también a través de experiencias, procesos y prácticas animadas por personas de carne y hueso, con vivencias concretas y envueltas en relaciones de poder. Las geógrafas feministas llevan décadas cuestionando ese olvido, recordándonos que el sesgo androcéntrico que ha marcado los análisis urbanos entraña el peligro de adoptar la experiencia de los hombres como un referente universal (García Ramón, 2005; McDowell y Massey, 1984; Monk y García Ramón, 1987; Silva, Ornat y Chimin, 2017).
We are aware of the challenge that this proposal implies for, as many previous works have already pointed out, the place of intersection between the subject, his emotions, and the city, has generated a dark and little-researched place (Lindon, 2009, 2012). Although the emotions start to acquire a growing relevance in geography and urban anthropology, (Bondi, Davidson and Smith, 2005; Enrique Rosas and Sánchez López, 2014; Lindón, Aguilar and Hiernaux, 2006; Soto and Aguilar, 2013), we cannot help but feel a certain suspicion for that unexplored corner, because in its existence we see a demonstration of how architecture and urbanism have been configured over the basis of assumptions that are objectivist and removed from the actual experience that people have in the city. We are concerned about the way in which this objectivism may lead us to oversee the fact that the city is constructed also through experiences, processes, and practices animated by persons of flesh and bone, with specific experiences, and involved in power relations. Feminist geographers have been questioning this neglect for decades, reminding us that the androcentric bias that has characterized urban analysis implies the risk of adopting the experience of men as a universal referent (García Ramón, 2005; McDowell and Massey, 1984; Monk and García Ramón, 1987; Silva, Ornat and Chimin, 2017). 
Gracias a todas estas críticas ha sido posible introducir la perspectiva de género en los estudios urbanos y hacer mucho más explícita la voluntad de llevar a cabo investigaciones transformadoras y comprometidas con las ciudades que habitamos. Sin embargo, pensamos que sigue existiendo cierto recelo a la hora de incorporar las dimensiones emocionales y subjetivas a los análisis sobre el espacio. En este sentido, coincidimos con Héctor Quiroz cuando apunta que "existen otros órdenes -que no desórdenes- en la conformación de las ciudades, y que las herramientas de la razón no son suficientes para explicarlos" (Quiroz, 2015, p. 13).

Por último, tras haber reflexionado sobre la propuesta de David Harvey (2012), que alude al papel de los movimientos sociales urbanos como creadores de "espacios de esperanza", nos proponemos mostrar el papel que juegan las emociones en resistencias cotidianas, pues articuladas desde lugares informales y protagonizadas por personas anónimas, pueden llegar a ser igualmente subversivas y esperanzadoras. Es decir, trataremos de mostrar cómo el uso de una perspectiva feminista en el análisis de la ciudad -junto a una metodología que permita dar cuenta de las emociones emergidas en la experiencia cotidiana de lo urbano- nos acerca a otro tipo de resistencias menos exploradas, pero igualmente importantes a la hora de transformar y mejorar los espacios habitados.
Thanks to all these critiques, it has been possible to introduce the gender perspective into urban studies and make much more explicit the will to carry out research that is transforming and committed to the cities we inhabit. However, we believe that there is still some reserve when incorporating the emotional and subjective dimensions into the analysis of space. In this sense, we agree with Héctor Quiroz when he points out that "there are other orders -not disorders- in the conformation of the cities, and which the tools of reason are insufficient to explain" (Quiroz, 2015, p. 13).

Finally, after some reflection on a proposal by David Harvey (2012), that refers to the role of social urban movements as creators of "spaces of hope", we are intent on showing the role that emotions play in everyday resistances because, articulated from within informal places and protagonized by anonymous individuals, they can become equally subversive and hopeful. That is to say, we shall attempt to demonstrate how, by using a feminist perspective in the analysis of the city -along with a methodology that allows the recording of the emotions emerged in the everyday experience of the urban-, we get closer to different, less explored types of resistances, but which are equally relevant in the transformation and improvement of the inhabited spaces. 
Con el fin de responder a los objetivos planteados, revisaremos la noción de "Derecho a la Ciudad", para luego detenernos en diferentes trabajos de carácter etnográfico y centrados en la cuestión urbana que nos han resultado significativos a la hora de resolver nuestros interrogantes. La selección de estos trabajos, limitada por motivos de extensión y parcial por la priorización de nuestros objetivos, abarca aquellos análisis que centran su atención en las desigualdades de género y se sitúan en una perspectiva epistemológica que atiende al valor de las dimensiones emocionales en su conexión con el habitar la ciudad. Prevalecerán, no obstante, escenarios en los que hemos realizado nuestros propios trabajos etnográficos, concretamente en la ciudad de Granada.

\section{El derecho a la ciudad desde una mirada feminista: el sentido de pertenencia}

La noción de "derecho a la ciudad" (Lefebvre, 1969), a la luz de su impacto en la literatura sobre cuestiones urbanas, sus más de cinco décadas de trayectoria y el renovado uso que hacen de ella muchos movimientos sociales, parece haberse convertido en una de las herramientas teóricas más relevantes para interrogarse sobre la ciudad y sus conflictos. Nosotras también llegamos a esta sugerente noción desde nuestra preocupación por mostrar
With the purpose of responding to the objectives posed, we shall review the notion of "Right to the City", to then stop and look at different works of an ethnographic nature, and centered around the urban question, that have been relevant in helping us solve our own questions. The selection of these works, limited for reasons of extensiveness and partial for its prioritization of our goals, encompasses those analysis that focus their attention on gender inequalities and are situated in an epistemological perspective that responds to the emotional dimensions in their connection with living the city. However, the scenarios where we have carried our own ethnographic studies will have prevalence, specifically in the city of Granada.

\section{The right to the city from a feminist perspective: The sense of belonging}

The notion of "right to the city" (Lefebvre, 1969), in the light of its impact on the literature about urban issues, its over five decades of history, and the renewed use that many social movements make of it, have seemingly transformed it into one of the most relevant theoretical tools when inquiring about the city and its conflicts. We also arrived at this appealing notion through our own preoccupation of exposing how the city reproduces gender inequalities, understanding 
cómo la ciudad reproduce las desigualdades de género, entendiendo esta noción de una forma interseccional (Lugones, 2011; Viveros Vigoya y Gregorio Gil, 2014).

La teoría de Lefebvre analiza cómo los procesos de urbanización, catalizadores del excedente económico que trae consigo la producción industrial de mediados del siglo XX, incrementan las desigualdades y los conflictos en la vida urbana. Este perverso proceso que destruye las antiguas ciudades y sus estilos de vida, se cobra como víctima principal a la clase obrera, pues es la más debilitada y desprotegida frente a un paradigma urbano que subordina la vida al crecimiento económico. Así, además de la tradicional miseria proletaria, Lefebvre identifica una nueva dimensión de explotación, "la miseria del hábitat" (Lefebvre, 1969, p. 166), que impacta de lleno sobre las clases trabajadoras y las condena a una "cotidianidad organizada" por la sociedad de consumo.

Para superar esta situación de conflicto, según Lefebvre, sería necesario devolver a la ciudad esa dimensión de realidad oscurecida por el "economismo liberal", logrando que la urbe sea un espacio en el que prevalezca el valor de uso sobre el valor de cambio, o un espacio en el "que la realidad urbana esté destinada a los "usuarios" y no a los especuladores, a los promotores capitalistas, a los planes de los técnicos" (1969, p. 151). Esa centralidad urbana, definida por las necesidades del mercado, debería transformarse y dar paso this notion in an intersectional way (Lugones, 2011; Viveros Vigoya and Gregorio Gil, 2014).

Lefebvre's theory analyzes how the urbanization processes, catalysts of the economic surplus that arrives with mid-20 th Century industrial production, increase the inequalities and the conflicts in urban life. This perverse process that destroys the old cities and their lifestyles, claims the working classes as main victims, since they are the most debilitated and helpless before an urban paradigm that subordinates life to economic growth. Thus, besides the traditional proletarian poverty, Lefebvre identifies a new dimension of exploitation, "the poverty of the habitat" (Lefebvre, 1969, p. 166), which has a direct impact on the working classes, and sentences them to an "everydayness organized" by the consumer society.

To overcome this condition of conflict, according to Lefebvre, it would be necessary to restore to the city that dimension of reality obscured by the "liberal economicism", making the city become a space where the value of use prevails over the value of exchange, or a space with "an urban reality for 'users' and not for capitalist speculators, builders, and technicians (1969, p. 151). This urban centrality, defined by market needs, should transform, and give way to a new center dictated by will of the urban society in its whole. However, by being the working classes those who have suffered the most the consequences of 
a un nuevo centro dictado por la voluntad de la sociedad urbana en todo su conjunto. Sin embargo, al ser la clase obrera la que más ha sufrido las consecuencias de que la ciudad esté organizada en base al crecimiento industrial y la que menos ha podido disfrutar de los resultados que ese crecimiento comporta, debe ser el sujeto político de esta lucha:

"Sólo el proletariado puede volcar su actividad social y política en la realización de la sociedad urbana [...] para y por quien la ciudad y su propia vida cotidiana en la ciudad se tornan obra, apropiación, valor de uso (y no valor de cambio) sirviéndose de todos los medios de la ciencia, el arte, la técnica, del dominio de la naturaleza material" (Lefebvre, 1969, p. 168).

David Harvey $(2008,2012)$ también defiende que este derecho ha de concretarse en una gestión más democrática del excedente económico, situando la ciudad como un escenario para la lucha anticapitalista. No obstante, consciente de las estrecheces del marxismo más ortodoxo, plantea repensar los conceptos de trabajo y clase, pues no están únicamente condicionados por el lugar de trabajo y producción, sino también por espacios de reproducción social, como el hogar. A pesar de que Harvey reconoce que la lucha de clases debe contemplar los derechos de todos los trabajadores urbanos, "sectores informales ahora masivos, caracterizados por el trabajo temporal, precario y no organizado" (Harvey, 2012, p. 204), su propuesta nos hace preguntarnos por cómo traducir estos the city being organized on the basis of industrial growth, and who have been the least able to enjoy the results that this growth entails, must be the political subject of this struggle:

"Only the proletariat can invest its social and political activity in the realization of urban society [...] for whom and by whom the city and his own daily life in it become oeuvre, appropriation, use value (and not exchange value), by using all the means of science, art, technology and the domination over material nature" (Lefebvre, 1969, p. 168).

David Harvey $(2008,2012)$ also argues that this right must materialize in a more democratic management of the economic surplus, placing the city as a scenario for anti-capitalist struggle. However, aware of the narrowmindedness of more orthodox types of Marxism, he proposes to rethink the concepts of work and class, because they are not only conditioned by the place of work and production, but also by spaces of social reproduction, like the home. Despite Harvey's acknowledgement that the class struggle must contemplate the rights of all the urban workers, "the now massive informal sectors characterized by temporary insecure, and non-organized labor" (Harvey, 2012, p. 204), his proposal makes us wonder how to translate these notions into political practice. On the other hand, it is not ultimately clear if this category of "urban workers" includes persons that carry out work that is not monetized or recognized by the parameters of the market. 
planteamientos a la práctica política. Por otra parte, tampoco termina de quedar claro si en esta categoría de "trabajador urbano" quedan incluidas las personas que realizan trabajos que no están monetarizados, ni reconocidos por los parámetros del mercado.

Frente a las sospechas que nos generan los ejes que definen al sujeto que sufre la "miseria del hábitat" o a quiénes han de ser artífices de la transformación radical urbana, consideramos urgente seguir contribuyendo al debate sobre la multiplicidad de mecanismos que privan a las personas de compartir la ciudad como espacio de relación, de reconocimiento y ejercicio de ciudadanía. Desde nuestros posicionamientos feministas, creemos que la clase social por sí misma no es suficiente para explicar estas violencias y que las desigualdades sociales no pueden leerse en toda su complejidad sin buscar cuáles son las conexiones del capitalismo con el heteropatriarcado.

Por otra parte, entendemos que la idea de "derecho a la ciudad", más allá de la dimensión relacional que propone Lefebvre (1969), debería concedernos la posibilidad de explicar las dinámicas de desigualdad que se crean en espacios urbanos concretos con el fin de poder identificar todos los ejes de poder que atraviesan las relaciones que se dan en ellos. Al igual que otras autoras (Buckingham, 2011; Fenster, 2005), nos preguntamos: ¿hasta qué punto la noción lefebvriana de derecho a la ciudad puede, sin tomar en cuenta el género,
Considering our mistrust for the axes that define the subject that suffers the "poverty of habitat", or those who are supposed to be the architects of the radical urban transformation, we consider it urgent to keep contributing to the debate on the multiplicity of mechanisms that prevent people from sharing the city as a space of relation, of recognition, and for the exercise of citizenship. From our feminist positions, we feel that the social class itself is insufficient to explain these acts of violence, and that the social inequalities cannot be understood in all their complexity without finding out what connections are there between capitalism and the heteropatriarchy.

On the other hand, we understand that the idea of "right to the city", beyond the relational dimension proposed by Lefebvre (1969), should grant us the possibility of explaining the dynamics of inequality created in the actual urban spaces with the purpose of identifying all the axes of power that crisscross the relations that take place in them. Just like other authors (Buckingham, 2011; Fenster, 2005), we wonder: to what point the lefebvrian notion of right to the city may, leaving aside gender, be sensitive to the differences and particularities that characterize each one of the persons comprising the city?

To solve this question and prevent that sort of blindness that leads us to take for granted the existence of a universal citizen, we find the proposal by Fenster (2005) most interesting. Besides inquiring into the possibility of using the 
ser sensible a las diferencias y particularidades que caracterizan a cada una de las personas que componen la urbe?

Para solventar esta cuestión y evitar esa especie de ceguera que nos lleva a dar por hecho la existencia de un ciudadano universal, nos resulta muy interesante la propuesta de Fenster (2005), quien, además de indagar en la posibilidad de usar los espacios y participar en su transformación, nos invita a analizar los sentimientos de pertenencia que generamos hacia los diferentes lugares que componen nuestro mapa urbano. Partiendo de que sentirnos parte de un espacio implica la repetición de prácticas que nos facilitan su apropiación (Certeau citado en Fenster, 2005), entendemos que ese sentimiento de pertenencia condensa una serie de dimensiones que nos interesa especialmente traer aquí.

La primera de ellas, y basándonos en el carácter sociocultural de nuestros sentimientos o emociones $^{5}$ (Ahmed, 2014; Fernández, 2011; Jaggar, 1989; Le Breton, 2013), nos conduce a pensar que nuestras opciones para desarrollar sentimientos de pertenencia tienen mucho que ver con las posiciones sociales que ocupamos.

5 La diferenciación entre sentimientos y emociones sigue siendo objeto de discusión en ciencias sociales. En nuestro caso, y siguiendo la propuesta de Sarah Ahmed (2014), usamos ambos términos indistintamente para no reproducir dicotomías similares a razón/emoción o cuerpo/mente, que sugieren que la emoción es una reacción física y primaria frente al sentimiento, que sería una elaboración posterior y más razonada de la emoción. spaces and participating in their transformation, she invites us to analyze the feelings of belonging we generate towards different places that compose our urban map. Based on the notion that feeling part of a space implies the repetition of practices that facilitate its appropriation (Certeau quoted in Fenster, 2005), we understand that this feeling of belonging condenses a series of dimensions that we are especially keen on bringing here.

The first one of them, and based on the sociocultural character of our feelings or emotions ${ }^{5}$ (Ahmed, 2014; Fernández, 2011; Jaggar, 1989; Le Breton, 2013), leads us to think that our chances of developing feelings of belonging have a lot to do with the social positions we occupy.

This way, the emotions experimented in the city reveal the differences produced as a consequence of racial, gender, sexuality, or class inequalities, the same ones that, frequently, expel those who embody alterity from many of their spaces. Secondly, we wish to highlight how the exploration of the emotions generated by the feeling of belonging forces us also to step back to the scale of the everyday life and to subjective

5 The differentiation between feelings and emotions is still subject of debate in the social sciences. In our case, and following Sarah Ahmed's (2014) proposal, we use both terms indistinctively, so as to avoid reproducing dichotomies like reason/emotion or body/ mind, which suggest that emotion is a physical and primary reaction, versus feeling, which would be a subsequent and more reasoned elaboration of emotion. 
De esta forma, las emociones experimentadas en la ciudad revelan las diferencias producidas como consecuencia de desigualdades raciales, de género, sexualidad o de clase, las mismas que, a menudo, expulsan a quienes encarnan la alteridad de muchos de sus espacios. En segundo lugar, queremos subrayar cómo la exploración de emociones a la que nos lleva el sentimiento de pertenencia, nos obliga además a retrotraernos a escalas de la vida cotidiana y a conocimientos subjetivos y experienciales, pues es en lo ordinario y en las rutinas urbanas donde dicha pertenencia se va forjando y adquiriendo significado.

De este modo, cuando nos referimos a derecho a la ciudad, además de las dos dimensiones que claramente se identifican en la propuesta de Lefebvre, relativas a usar la ciudad y participar en su reinvención, nos interesa enfatizar una tercera: la posibilidad de generar sentimientos de pertenencia hacia los lugares. Uso, participación y pertenencia son, a nuestro juicio, los ejes que articulan el ejercicio del derecho a la ciudad y no podemos entenderlos al margen de las posiciones de género, sexualidad, raza o clase social que ocupan quienes habitan la urbe, pues moldean sus relaciones cotidianas con el entorno y con el resto de sus habitantes, atravesando, además, sus negociaciones por y en el espacio urbano. and experiential knowledge, for it is in the ordinary and in the urban routines where the said belonging gets gradually forged and acquires meaning.

This way, when we refer to right to the city, besides these two dimensions that are clearly identified in Lefebvre's proposal, pertaining to using the city and participating in its reinvention, we are interested in emphasizing a third one: the possibility to generate feelings of belonging towards the places. Use, participation, and belonging are, according to us, the axes that articulate the exercising of the right to the city, and we cannot understand them separated from stances on gender, sexuality, race, or social class that of those who inhabit the city, for they shape their everyday relations with the surroundings and the rest of its inhabitants, running through, also, their negotiations for and in the urban space. 


\section{Etnografíar las emociones en el tejido de resistencias del espacio urbano}

Partiendo de que en el ejercicio del derecho a la ciudad están imbricadas las emociones que nos conectan con los espacios que habitamos, proponemos acercamientos metodológicos que posibiliten la emergencia de esas emociones que se entrelazan con las formas de habitar la ciudad, así como con las estrategias de resistencia y solidaridad que se van tejiendo. Coincidimos con Flam (2005), Jasper (2012) o Ahmed (2014) en que las emociones resultan cruciales para una mayor comprensión de las prácticas de movimientos sociales además de permitir vislumbrar los vínculos afectivos que se van tejiendo en su interior y sin los cuales no podrían mantener sus luchas y resistencias.

Tomando en cuenta estas aportaciones, consideramos las emociones como saberes experienciales, formas de conocer que emergen gracias a procesos cotidianos. Lo ordinario, tan a menudo silenciado y desvalorizado, implica para nosotras una escala más en la conformación de prácticas políticas y legítimas con las que ejercer el derecho a la ciudad. En este sentido, nos parece fundamental dirigir nuestra mirada hacia esa cotidianidad, no sólo por su poder para aterrizar, en los espacios de lo concreto, una noción de derecho a la ciudad que muchas veces se nos torna difusa,

\section{Ethnographing emotions in the fabric of resistances of urban space}

Starting from the fact that in the exercising of the right to the city the emotions that connect us with the spaces we inhabit overlap, we propose methodological approaches that enable the emergence of these emotions that are intertwined with the ways of inhabiting the city, as well as with the strategies of resistance and solidarity that are being woven. We coincide with Flam (2005), Jasper (2012) or Ahmed (2014) in that emotions become crucial for a greater understanding of the practices of social movements, besides allowing to discern the affective bonds that are being woven inside it and without which they could not maintain their struggles and resistances.

Taking these contributions into account, we consider emotions as experiential knowledge, ways of knowing that emerge thanks to everyday processes. The ordinary, so often silenced and undervalued, implies for us another scale in the conformation of political and legitimate practices with which to exercise the right to the city. In this sense, we deem essential to direct our gaze towards this everyday life, not only for its power to ground, in the domains of the concrete, a notion of right to the city that often seems blurred, but because when we question ourselves 
sino porque al interrogarnos sobre las prácticas de resistencia, queremos insistir en la necesidad de problematizar esos "espacios de esperanza" (Harvey, 2012) a los que ya nos referimos en la introducción. Quizá nosotras somos un poco más escépticas con el activismo por el derecho a la ciudad, pues nos resistimos a creer que esté conformando lugares exentos de relaciones de poder o con la capacidad de representar a todas las personas que sufren las "miserias del hábitat". Queremos plantear la existencia de otras formas de organización, estructuradas de manera informal $y$ en ámbitos cotidianos ${ }^{6}$, que, a pesar de haber sido menos exploradas, poseen un gran potencial para marcar el devenir de nuestros barrios y ciudades. Creemos que para descubrirlas es necesario situar experiencias y sentimientos, pero también recuerdos, fuera de los lugares legitimados y reconocidos como espacios políticos. Estas resistencias cotidianas están protagonizadas por personas que, privadas del derecho a la ciudad, "normalizan" la violencia como parte de su relato de vida y perciben la urbe como inhóspita y hostil. Tales experiencias, cargadas de emociones y memorias encarnadas, se van condensando al habitar la ciudad, por lo que nuestra apuesta se centra en situarlas como prácticas políticas, pues entendemos que cuando la violencia es rutina, la resistencia también forma parte de ésta.

6 Para profundizar en esta cuestión nos remitimos al trabajo de campo de Paula Pérez Sanz (Gregorio Gil, Pérez Sanz y Espinosa Spínola, en prensa; Pérez Sanz, 2019). about the practices of resistance, we want to insist in the necessity of problematizing these "spaces of hope" (Harvey, 2012) that we already mentioned in the introduction. Perhaps we are a bit more skeptical regarding activism for the right to the city, because we resist to believe that it may be producing places devoid of relations of power or with the ability to represent all those who suffer the "poverty of the habitat". We wish to pose the existence of other forms of organization, structured in an informal way and in everyday contexts $^{6}$, which, despite having been less explored, possess a great potential to mark the fate of our neighborhoods and cities. We believe that, in order to discover them, it is necessary to put experiences and feelings, but also memories, outside of the places legitimized and recognized as political spaces. These everyday resistances are protagonized by individuals who, deprived from the right to the city, "normalize" violence as part of their life narrative and perceive the city as inhospitable and hostile. Such experiences, charged with emotions and embodied memories, are being condensed into the living of the city, so our bet is focused on situating them as political practices, for we understand that when violence is routine, resistance is also a part of it.

6 To delve into this issue we refer to the field work of Paula Pérez Sanz (Gregorio Gil, Pérez Sanz and Espinosa Spínola, 2020; Pérez Sanz, 2019) 
Desde esta convicción, tratamos entonces de responder al objetivo de generar estrategias metodológicas con las que visibilizar las luchas cotidianas por el derecho a la ciudad. Con este fin, hemos encontrado pertinente rescatar trabajos que nos resultan muy sugerentes porque de alguna forma restituyen el valor de las memorias encarnadas (Valle, 1999) y las experiencias cotidianas de la ciudad. Además, nos han despertado un gran interés porque, aunque no necesariamente se sitúan como etnografías feministas, cuestionan los presupuestos objetivistas que han excluido el valor de las emociones como fuente de conocimiento en las ciencias sociales en general, y en los análisis urbanos en particular. Es por ello que las etnografías a las que nos referiremos, desde su sensibilidad para apreciar las experiencias cotidianas y emocionales de las rutinas conflictivas que llenan la ciudad de significados, nos permiten traer visiones encarnadas de la urbe, así como de las estrategias para habitarla. Los trabajos escogidos, en definitiva, invitan a reflexionar acerca del papel que juegan estos saberes emocionales como desencadenantes de políticas orientadas a ejercer el derecho a la ciudad. En nuestro discurrir por la lectura de diversas etnografías sobre el espacio urbano y el género nos encontramos con dos emociones: el miedo y el sentimiento de no pertenencia o de "estar fuera de lugar".
From this conviction, we then try to respond to the objective of generating methodological strategies with which to make visible the everyday struggles for the right to the city. With this purpose, we found pertinent to rescue works that to us are very appealing because in some way they restore the value of embodied memories (Valle, 1999) and the everyday experiences of the city. Besides, they have awakened in us great interest because, although they do not necessarily qualify as feminist ethnographies, they nonetheless question the objectivist assumptions that have excluded the value of emotions as source of knowledge in the social sciences in general, and in urban analysis in particular. This is why the ethnographies to which we will be referring, from their sensitivities for the appreciation of the everyday experiences and emotions in the conflicting routines that fill the city with meanings, they allow us to extract embodied visions of the city, as well as the strategies to inhabit it. The selected works, ultimately, are an invitation to reflect on the role these emotional knowledges play as triggers of policies oriented to the exercising of the right to the city. In our going over readings of different ethnographies about urban space and gender we encountered two emotions: fear and the sense of non-belonging or of "being out of place". 
El miedo es, sin duda, una de las emociones más exploradas en relación con las construcciones de género y la ciudad. Los trabajos de Teresa del Valle $(1999,2000)$ han sido reveladores para comprender de qué forma el sistema de género actúa como un principio regulador de nuestras sociedades y configura la ordenación urbana, sustentando además los imaginarios del miedo de las mujeres en la ciudad. Tales imaginarios se recrean en las biografías individuales y dan lugar a formas generizadas de habitar la urbe. Ya sea por el temor a un mundo percibido como ajeno o por el terror a la violencia sexual en muchos de sus tiempos y espacios, la ciudad se presenta para las mujeres como un lugar prohibido. Algunos de estos acercamientos etnográficos a los temores vividos en la ciudad han aportado interesantes herramientas analíticas, como los "imaginarios de la inseguridad" o las "geografías del miedo" (Reguillo, 1998, 2008; Valle, 1999). Nos detendremos en algunos de estos trabajos etnográficos localizadas en contextos muy concretos y tan distintos como Ciudad de México, Jerusalén, San José de Costa Rica, Ponta Grossa, Manresa, Granada, Sevilla o Euskal Herria.

Paula Soto (2013) en su trabajo "Entre los espacios del miedo y los espacios de la violencia: discursos y prácticas sobre la corporalidad y las emociones" nos acerca a las experiencias cotidianas de las mujeres que habitan una colonia popular de Ciudad de México. La autora desmenuza con gran habilidad las narraciones que las mujeres comparten sobre su día a
Fear is without any doubt one of the most explored emotions in relation with constructions of gender and the city. The work of Teresa del Valle (1999, 2000) has been revealing to understand in what way the gender system acts as a regulating principle of our societies and configures the urban order system, sustaining also the imaginaries of fear of women in the city. Such imaginaries are recreated in the individual biographies and result in gendered forms of inhabiting the city. Be it for fear of a world perceived as alien or the terror of sexual violence in many of its times and spaces, the city is presented as a forbidden place for women. Some of these ethnographic approaches to the fears lived in the city have contributed interesting analytical tools, like the "imaginaries of insecurity" or the "geographies of fear" (Reguillo, 1998, 2008; Valle, 1999). We shall review some of these ethnographic works located in very precise and diverse contexts such as Mexico City, Jerusalem, San Jose de Costa Rica, Ponta Grossa, Manresa, Granada, Seville or Euskal Herria.

Paula Soto (2013) in her work "Entre los espacios del miedo y los espacios de la violencia: discursos y prácticas sobre la corporalidad y las emociones" (Between the spaces of fear and the spaces of violence: discourses and practices on corporality and the emotions) brings us closer to the everyday experiences of women that inhabit a specific colonia in Mexico City. The author 
día, logrando anclar esta emoción a espacios concretos de la colonia Doctores y a imaginarios que, atravesados por dimensiones de género, alimentan un relato sobre el espacio urbano como un lugar masculinizado y peligroso. Su etnografía permite vislumbrar cómo, efectivamente, el miedo condiciona nuestros modos de habitar y crea "barreras simbólicas que se entrelazan con las particularidades del lugar y terminan siendo los mecanismos más sutiles, pero más efectivos, para demarcar un paisaje emocional en la ciudad" (Soto, 2013, p. 217). Tratando de alejarse de una imagen victimizante, la autora se interesa por las resistencias cotidianas desarrolladas por mujeres que, a partir de gestos como caminar acompañándose, "reutilizan un saber cotidiano y se sitúan como sujetos" (Soto, 2013, p. 215). Aunque prácticas de este tipo puedan parecer meramente anecdóticas, el análisis presentado revela su carácter colectivo y las posibilidades que otorgan a la hora de compartir saberes sobre la ciudad y tomar conciencia de las desigualdades que muchas mujeres afrontamos al habitarla.

También Tovi Fenster (2005), sirviéndose de entrevistas en profundidad hechas a mujeres afincadas en Jerusalén, muestra cómo han generado sus mapas de lugares prohibidos, pero también deseados. Si en la propuesta de Paula Soto encontramos una enorme capacidad para anclar el miedo a espacios, sujetos y tiempos, coincidimos con Anna Ortiz (2006) en que quizá lo más sugerente en el trabajo de Tovi Fenster es su poder para desmitificar la noción clásica analyzes with great skill the stories these women share about their ay-to-day, managing to anchor these emotions to concrete spaces in Colonia Doctores and to imaginaries that, crisscrossed by issues of gender, nurture a narrative about urban space as a place that is masculinized and dangerous. Her ethnography allows us to envisage how, effectively, fear conditions our modes of inhabiting and creates "symbolic barriers that are intertwined with the specificities of the place and end up being the subtlest, yet most effective mechanisms to trace an emotional landscape of the city" (Soto, 2013, p. 217). Trying to stay away from victimizing images, the author is drawn to the everyday resistances developed by women who, based on gestures like walking side by side, "reutilize an everyday knowledge and are situated as subjects" (Soto, 2013, p. 215). Although practices of this kind may seem merely anecdotic, the analysis presented reveals its collective character and the possibilities it gives when sharing knowledge about the city and creating awareness of the inequalities that many women have to face when inhabiting it.

Also, Tovi Fenster (2005), using in-depth interviews with women living in Jerusalem, shows how they have generated maps of forbidden, but also desired, places. If in Paula Soto's proposal we find a great capacity to anchor fear to spaces, subjects, and times, we coincide with Anna Ortiz (2006) that perhaps 
de sentimiento de pertenencia, que normalmente se funda sobre espacios sagrados o de fuerte simbolismo para la comunidad. Alejándose de esta visión más tradicional, la autora consigue mostrar cómo las mujeres con las que conversa construyen este sentir a partir de deseos y necesidades relacionadas con sus prácticas diarias en entornos cotidianos. De este modo, los temores generados por esas arquitecturas del miedo o por espacios altamente masculinizados, debilitan su sentimiento de pertenencia y por tanto el derecho a la ciudad. En el extremo opuesto se sitúan los espacios deseados, aquellos que conectan con el recuerdo y lo cotidiano, y que en muchos casos coinciden con los barrios habitados durante la infancia, los aledaños de centros educativos y espacios que, por lo general, tienen que ver con la vida comunitaria y las tareas del cuidado. El apego a este tipo de lugares genera un sentimiento de intimidad y confianza que afianza las redes de pertenencia y aumenta la agencia de las mujeres en todos estos lugares.

En una localización bien distinta, la capital de Costa Rica, y acercándose a las trabajadoras del sexo, el trabajo de Mariana Rojas (2014) nos muestra el potencial de la etnografía, no sólo para desvelar las particulares "geografías del miedo", sino también para deconstruir una noción unitaria y colonizadora de la categoría "mujer" -como sujeto de ese miedo- que no hace sino ocultar otro tipo de violencias relacionadas con la pobreza o con la pertenencia a sectores sociales altamente estigmatizados. Su what's most compelling about the work of Tovi Fenster is her ability to demystify the classical notion of feeling of belonging, which is usually based on spaces that are sacred or of strong symbolism for the community. Moving away from this more traditional vision, the author manages to show how the women with whom she converses build up this feeling over the basis of desires and needs related to their daily practices in everyday environments. By doing so, the fears generated by these architectures of fear, or by highly masculinized spaces, debilitate their sense of belonging and therefore the right to the city. On the opposite side, the desired spaces are situated, those that connect with memory and the everyday, and that in many cases coincide with the neighborhoods inhabited during childhood, those close to educational centers and spaces that, in general, have to do with community life and caretaking. The attachment to these types of places generates a feeling of intimacy and trust that strengthens the networks of belonging and increases the agency of women in all these places.

In a completely different location, the capital city of Costa Rica, and reaching out to sex workers, Mariana Rojas's (2014) work shows us the potential of ethnography not only to reveal the particular "geographies of fear", but also in deconstructing a unitarian and colonizing notion of the category "woman" - as subject of this fear-which only hides another type of violence related to poverty or to belonging to 
investigación nos obliga a plantearnos nuevos interrogantes y a concebir la vulneración del derecho a la ciudad no sólo como una expropiación del espacio urbano, sino como fruto de las "miserias del hábitat" motivadas por desigualdades de género, clase y raza que, como en el caso de las trabajadoras del sexo, se solapan en un "habitar cotidiano" desarrollado de manera forzosa en zonas que evocan fuertes sentimientos de inseguridad.

\begin{abstract}
"Ahondar en el tema del miedo y la inseguridad en la ciudad cobra relevancia al momento de analizar la forma en que las mujeres trabajadoras del sexo practican y habitan la ciudad, al entender este habitar de una manera integral, donde no sólo se presta atención a los lugares que visitan o no las mujeres, sino también la relación que cobra su trabajo - que se encuentra expuesto a múltiples amenazas - con el espacio habitual que ocupan en la ciudad" (Rojas, 2014, p. 62).
\end{abstract}

Frente a esta inseguridad se articulan prácticas cotidianas de resistencia sustentadas en las redes de solidaridad que van tejiendo las mujeres que ejercen el trabajo sexual en esta zona. Esta etnografía indaga en la forma en que dichas redes actúan como un revulsivo para el miedo, pues pese a la competitividad que podría caracterizar al trabajo sexual, el principio de solidaridad prima por encima de todo cuando se ve comprometida la seguridad de las otras mujeres. Dicha situación se contrarresta mediante prácticas informales de vigilancia orientadas a highly stigmatized social sectors. Her research work forces us to pose new questions and to conceive the violation of the right to the city not only as an expropriation of the urban space, but as a byproduct of the "poverties of the habitat" motivated by inequalities of gender, class, and race that, as is the case with sex workers, overlap in an "everyday living" developed by force in areas that evoke strong sentiments of insecurity.

"Delving into the issues of fear and insecurity in the city becomes relevant when analyzing the way in which female sex workers practice and inhabit the city, by understanding this inhabiting in an integral way, where the attention is not only on the places that the women visit or not, but also on the relation that their work — which is exposed to multiple threats - acquires with the usual space they occupy in the city" (Rojas, 2014, p. 62).

In the face of this insecurity, everyday practices of resistance are articulated, supported on the networks of solidarity that the female sex workers in the area weave. This ethnography inquires into the way in which the said networks act as a remedy for fear for, despite the competitiveness that may characterize sex work, the principle of solidarity rules over everything else when the safety of the other women is compromised. This situation is countered by means of informal practices aimed at circulating information about the places and the clients with which the other partners are. 
vehicular información sobre el lugar y el cliente con el que se encuentran otras compañeras.

Por último, queremos terminar haciendo referencia al trabajo con el que Arrate Gutiérrez (2017) analiza el miedo con que viven las mujeres en las ciudades como un desencadenante de las movilizaciones feministas en Euskal Herria. La autora propone un acercamiento etnográfico a las manifestaciones del movimiento feminista vasco contra las agresiones machistas, en particular contra las que vienen ocurriendo en ambientes festivos en los que, bajo el "pretexto de la euforia festiva y el exceso de alcohol, parece que todo vale" (Gutiérrez, 2017 , p. 7). En esta ocasión, la estrategia de la que hacen uso las manifestantes es llamada por la autora -siguiendo a Rhodes (2001)"violencia performativa". Las manifestantes se reapropian y agencian el miedo infligiéndolo simbólicamente al hacer uso de diferentes elementos performativos que evocan los conflictos armados, como son la capucha, la noche, la vestimenta negra o el fuego. Además de la "violencia performativa" los grupos a los que esta autora se acerca proponen la autodefensa feminista como forma de enfrentar el miedo y responder a las violencias cotidianas que sufren las mujeres en las ciudades.

Sentirse fuera de lugar, sentir que determinados lugares de la ciudad no te pertenecen porque no encajas en el modelo heteronormativo -el modelo de ciudadano hombre, blanco, occidental,
Finally, we wish to end with a reference to the work with which Arrate Gutierrez (2017) analyzes the fear with which women live in the cities as a triggerer of the feminist mobilizations in Euskal Herria. The author proposes an ethnographic approach to the rallies of the Basque feminist movement against male aggressions, in particular those had been occurring in festive environments where, under the "pretext of festive euphoria and excess of alcohol, apparently anything goes" (Gutiérrez, 2017, p. 7). On this occasion, the strategy the protesters use is called "performative violence" by the author -following Rhodes (2001)- The protesters re-appropriate and agency fear, inflicting it symbolically by making use of different performative elements that evoke armed conflicts, such as the hood, the night, the black dress, or fire. Besides the "performative violence", the group this author approaches, proposes feminist self-defense as a way of facing fear and responding to the everyday violence that women suffer in the cities.

Feeling out of place, feeling that specific places in the city do not belong to you because you do not fit in the heteronormative model -the model of male citizen, white, western, heterosexualconstitutes another one of the emotions that emerge in different ethnographic works that address issues related to inequalities of gender and sexuality in the urban space. The spaces in 
heterosexual- constituye otra de las emociones que emergen en diferentes trabajos etnográficos que abordan cuestiones relacionadas con las desigualdades de género y sexualidad en el espacio urbano. Los espacios en los que nos sentimos fuera de lugar toman relación con un sentimiento de "otredad", de no encajar en las visiones hegemónicas de lo esperable o aceptable.

Como plantea Linda McDowell (2000), no responder a las expectativas desde las que se construyen ciertos espacios genera sentimientos de incomodidad y "no pertenencia". Por su parte, la sexualidad normativa, como señala Valentine (1997), se configura a través de determinados espacios urbanos organizados desde lógicas heterosexuales y pensados para mostrar y reafirmar continuamente esa sexualidad, generando sensaciones de malestar y de sentirse fuera de lugar en quienes, desde sus identidades no normativas, transitan esos puntos de la ciudad.

En relación con la noción de cuerpo como lugar y locus de la experiencia emocional, Cristina García (2013), en su trabajo de investigación titulado "De los no-espacios a los espacios de resistencia: aproximación etnográfica a las arquitecturas de poder en la ciudad de Granada", nos habla -autobiográficamentede su sentimiento de ser un "cuerpo fuera de lugar" en la ciudad en la que habita.

"Situarme cada vez más al margen del sistema heteronormativo, ha ido trayéndome nuevas percepciones de la ciudad en la que vivo [...] Ocupar un cuerpo, una sexualidad, unas which we feel out of place become related to a feeling of "otherness", of not fitting the hegemonic visions of the expectable or acceptable.

As posed by Linda McDowell (2000), not responding to the expectations from where certain spaces are constructed generates sentiments of uncomfortableness and "non-belonging". On its part, normative sexuality, as Valentine (1997) points out, is configured through particular urban spaces organized over the basis of heterosexual logics and devised to continuously expose and reaffirm that sexuality, generating feelings of unease and of being out of place in those who, from their nom-normative identities, circulate through those areas in the city.

Regarding the notion of body as a place and locus of the emotional experience, Cristina García (2013), in her research work entitled "De los no-espacios a los espacios de resistencia: aproximación etnográfica a las arquitecturas de poder en la ciudad de Granada" ("From nonspaces to spaces of resistance: an ethnographic approach to the architectures of power in the city of Granada"), speaks to us -autobiographicallyabout her feeling of being a "body out of place" in the city where she lives.

"Situating myself more and more outside the heteronormative system has brought me new perceptions about the city where I live [...] Occupying a body, a sexuality, practices, a community, and a thought that is subversive 
prácticas, una comunidad y un pensamiento que es subversivo de por sí con las normas de género me ha ido definiendo como "Cuerpo Fuera de Lugar", es decir, que he ido experimentando un sentimiento de marginalidad y exclusión en los espacios considerados "normales" (McDowell, 2000).

Desde mi posición -a veces elegida, y a veces impuesta- de mujer, bollera, feminista, queer; he experimentado otro tipo de agresiones y he visto cómo se agravan, he sido consciente de otras muchas que antes tenía naturalizadas, me he visto sin espacios propios o de seguridad, sin representación en los espacios públicos, he visto limitada mi movilidad y poner barreras al pensamiento, a determinadas actividades y a la expresión" (García, 2013, p. 6).

Para García (2013), sin embargo, son precisamente esas subjetividades, esos cuerpos fuera de lugar, los que se constituyen en "campos de batalla", siendo precisamente las sub-alteridades las que los convierten en "subversivas". Entre las estrategias que la autora señala para apropiarse de la ciudad estarían: la búsqueda de mapas y rutas alternativas, "más que evitar lugares, buscamos otros donde nos sentimos más libres e identificadas; la generación y construcción de 'espacios seguros' que nos permiten una experiencia más cómoda y sin agresiones" (García, 2013, p. 69) y el "estar juntas" o "salir en manada" en aquellos espacios en los que se ejercen todo tipo de violencias. Como comentará en su trabajo, la "manada de per se towards gender norms has defined me as a "Body out of place", that is, that I have been experiencing a sense of marginality and exclusion in the spaces considered as "normal" (McDowell, 2000).

From my position -sometimes chosen and sometimes imposed- as woman, lesbian, feminist, queer, I have experienced other types of aggressions and have seen them get worse. I've become aware of others I had naturalized before, I've seen myself without spaces of my own or of safety, with no representation in the public spaces, I've seen my mobility restricted and barriers placed on thought, on certain activities, and on expression" (García, 2013, p. 6).

For García (2013), however, it is precisely those subjectivities, those bodies out of place, that become "battlegrounds", being precisely the sub-alterities the ones that turn them into "subversive". Among the strategies the author points out to take ownership of the city are: the search for maps and alternative routes, "rather than avoiding places, we seek others where we feel freer and more identified; the generation and construction of "safe spaces" that allow us a more comfortable and aggression-free experience" (García, 2013, p. 69) and "being together" or "group outing" in those spaces where all kinds of violence is exerted. As she will comment in her work, the "pack of female dogs" constitutes a "strategy of political resistance that emerges 
perras" constituye una "estrategia de resistencia política que surge a partir de la sensación de empoderamiento que sentimos cuando salimos todxs juntxs" (García, 2013, p. 76). Dicha estrategia modifica el mapa de la ciudad y fomenta un sentimiento de pertenencia que le permite apropiarse del espacio público.

Muy interesante nos parece también el trabajo con el que María Rodó de Zárate (2016) incorpora la perspectiva interseccional y comparativa al analizar las violencias urbanas que sufren jóvenes lesbianas en ciudades no metropolitanas, comparando concretamente Manresa (Cataluña) y en Ponta Grossa (Brasil). La autora explora cómo la relación de estas jóvenes con entornos heterosexistas y adultocentristas limita su derecho a la ciudad, pero no deja de reconocer su agencia en gestos cotidianos que muestran una rebelión frente a ciudades cuyos usos y disfrute reproducen el consenso en torno a la heternormatividad. La ocupación de baños públicos, recovecos entre las calles o la creación de lugares "dominados por lesbianas" (Rodó de Zárate, 2016, p. 10) son algunos de los ejemplos que nos ofrece de cómo, mediante gestos cotidianos motivados por profundos malestares, se subvierte el orden establecido en la ciudad. from the sensation of empowerment we feel when we all go out together" (Garcia, 2013, p. 76). This strategy modifies the map of the city and fosters a feeling of belonging that enables the appropriation of public space.

We also find great interest in the work with which María Rodó de Zárate (2016) incorporates the intersectional and comparative perspectives when analyzing the urban violence young lesbians suffer in non-metropolitan cities, specifically comparing Manresa (Catalonia) and Ponta Grossa (Brazil). The author explores how the relation of these young women with heterosexist and adult-centred surroundings limits their right to the city, but still acknowledges their agency in everyday gestures that show a rebellion before cities whose use and enjoyment reproduce a consensus around heteronormativity. The use of public restrooms, nooks and crannies in the streets, or the creation of places "dominated by lesbians" (Rodó de Zárate, 2016, p. 10) are some of the examples offered to us of how, through everyday gestures motivated by deep discomforts, the established order in the city can be subverted. 
Otra dimensión que nos resulta crucial con relación al sentimiento de pertenencia es la centralidad que adoptan los cuidados ${ }^{7}$ cuando trascienden el denominado espacio doméstico y devienen formas de habitar la ciudad y resignificar el espacio público. Diferentes trabajos han visibilizado un conjunto de prácticas de cuidado que tienen lugar en el espacio público y que permiten a las mujeres reapropiárselo y desarrollar sentimientos de pertenencia.

Esta resignificación del espacio urbano, basada en el cuidado, la observamos en trabajos etnográficos como el de García Herrera, Díaz Rodríguez, García-García, Armas Diaz y García Hernández (2015), en el que las autoras indagan sobre el proceso mediante el que ciertas prácticas de resistencia vecinal movilizan el sentido de pertenencia y la vinculación afectiva hacia un lugar concreto en un barrio de Sevilla, el Parque Estoril. Este parque, que durante décadas evocaba sentimientos de miedo por su uso para la venta y consumo de drogas, se convierte en un espacio que el vecindario ocupa y reivindica hasta lograr adaptarlo a sus intereses: disponer de un lugar para el "enriquecimiento cultural, educativo y recreativo de sus usuarios" (García

7 Partimos de un concepto muy amplio de cuidados para referirnos a todos aquellos trabajos invisibilizados y feminizados que tienen relación con la gestión y el mantenimiento cotidiano de la vida, en sus dimensiones materiales y emocionales. Véase el número monográfico publicado en la revista Quaders-e y coordinado por María Offenhendem y Dolors Comas D'Argemir en el que se recogen interesantes reflexiones desde la antropología en torno al cuidado ("Reflexiones desde la antropología", 2017).
Another dimension that is crucial to us in regard to the feeling of belonging is the centrality that is adopted by care ${ }^{7}$ It transcends the so-called domestic space and becomes ways of inhabiting the city and re-signifying public space. Different works have made visible a set of practices of care that take place in the public space that allow women to re-appropriate it and develop feelings of belonging.

This re-signification of urban space, based on care, can be observed in ethnographic works like those by García Herrera, Diaz Rodríguez, Garcia-Garcia, Armas Diaz and García Hernández (2015), where the authors inquire about the process by which certain practices of neighborly resistance mobilize a sense of belonging and emotional bonding towards a specific place in a neighborhood in Seville, Parque Estoril. This park, which for decades evoked feelings of fear for its use in the sale and consumption of drugs, becomes a space that the neighbors use and vindicate until they eventually manage to adapt it to their interests: having a place for "cultural, educational, and recreational

$7 \quad$ We start from a rather broad concept of care to refer to all those tasks made invisible and feminized that bear relation to the everyday management and maintenance of life in its material and emotional dimensions. Please refer to the monographic issue published in Quaders-e magazine and coordinated by María Offenhendem and Dolors Comas D'Argemir, where interesting reflections from anthropology on the subject of care are collected ("Reflexiones desde la antropología", 2017). 
Herrera et al., 2015, p. 8). Mediante la reiteración de prácticas de cuidado -protagonizadas por mujeres- como celebraciones de cumpleaños, comidas populares $\mathrm{u}$ otros eventos con un fuerte significado comunitario, la ciudadanía se ha reapropiado de este parque. Ha sido la práctica de estos rituales cotidianos la que ha posibilitado la identificación emocional con el lugar, contribuyendo a su desestigmatización. Las emociones, como señalan las autoras, han jugado un papel fundamental en el proceso:

"La dimensión afectiva y las relaciones de amistad y vecindad se han forjado y fortalecido en el proceso de reivindicación y de territorialización de un espacio 'integral' que, como tal, atiende, al bienestar en sus aspectos materiales y emocionales, lo que constituye uno de los rasgos principales de este espacio público" (García Herrera et al., 2015, p. 11).

También Gregorio Gil (2015) evidencia, en su acercamiento etnográfico, las construcciones de género implícitas en las formas de participación que se despliegan en algunos barrios de la ciudad de Granada desde el llamado movimiento $15 \mathrm{M}^{8}$. Las mujeres con las que conversó, implicadas en dicho movimiento, sitúan el despertar de un sentimiento de pertenencia a su barrio, que no

8 Con la expresión $15 \mathrm{M}$ se hace referencia al movimiento ciudadano que arrancó en el Estado español a partir de la manifestación multitudinaria del 15 de mayo de 2011, que hunde sus raíces en el aumento de la indignación de la ciudadanía desde la crisis económica del 2008. Sobre este movimiento, en particular en la ciudad de Granada, véase el trabajo de tesis doctoral de Adriana Razquín (2014). enrichment of its users" (García Herrera et al., 2015 , p. 8). Through the reiteration of practices of care -protagonized by women- such as birthday celebrations, public meals, or other events with a strong sense of community, the citizens have re-appropriated this park. It has been the practice of these everyday rituals what has enabled the emotional identification with the place, contributing to its de-stigmatization. The emotions, as the authors point out, have played a key role in the process:

"The emotional dimension and the relations of neighborly friendship have forged and strengthened the process of vindication and territorialization of an 'integral' space that, as such, caters to the wellbeing in its material and emotional aspects, in what constitutes one of the main features in this public space" (García Herrera et al., 2015, p. 11).

Gregorio Gil (2015) also provides evidence, in his ethnographic approach, of the gender constructions implicit in the forms of participation unfolded in some quarters in the city of Granada by the so-called $15 \mathrm{M}$ movement ${ }^{8}$. The women with which he spoke, associated to this movement, associate the awakening of a feeling

8 The expression $15 \mathrm{M}$ refers to the movement that took off in Spain after the protests of May $15^{\text {th }}, 2011$, whose roots can be traced to an increase in citizen discontent after the economic crisis of 2008. About this movement, especially in the city of Granada, see the doctoral thesis work by Adriana Razquín (2014) 
habían vivido antes, a partir de acciones cotidianas con el vecindario, entre las que señalan: compartir una conversación en el autobús, saludarse por la calle, intercambiar comida o regar sus plantas. Los hombres, sin embargo, enfatizan su sentido de pertenencia al barrio desde su participación en acciones políticas relacionadas con concentraciones y/o manifestaciones, por ejemplo, contra los desahucios.

\section{Conclusiones}

Con este trabajo nos hemos propuesto mostrar el valor de la etnografía feminista como una metodología desde la cual restituir la dimensión política de las prácticas cotidianas desplegadas al habitar la ciudad, o si se quiere, al practicar y hacer efectivo, el derecho a la ciudad.

Acercarnos a la práctica del derecho a la ciudad desde una perspectiva feminista ha implicado revisitar y problematizar esta noción propuesta por Lefebvre (1969) para incorporar otros regímenes de poder y desigualdad, diferentes al de clase, que estructuran la vida urbana. Aunque los ejes de desigualdad en los que nos hemos detenido - género, sexualidad, edad y raza - han sido suficientemente teorizados desde una perspectiva interseccional, en esta ocasión hemos querido mostrarlos a la luz de la metodología etnográfica. Para ello analizamos diferentes trabajos de investigación, realizados en contextos muy diversos, que se acercan a las prácticas cotidianas desarrolladas en el espacio of belonging to their neighborhood, which they hadn't experienced before, to everyday actions with the neighborhood, among which are: sharing a conversation in the bus, greeting each other in the street, exchanging food or watering their plants. Men, however, emphasize their sense of belonging through their participation in political activities related to rallies and/or protests, for instance, against layoffs.

\section{Conclusions}

With this work we have set out to show the value of feminist ethnography as a methodology from which to restore the political dimension of everyday practices deployed when inhabiting the city or, in other words, when exercising and fulfilling the right to the city.

Approaching the practice of right to the city from within a feminist perspective has implied revisiting problematizing this notion proposed by Lefebvre (1969) to incorporate other power and inequality regimes, different to those of class, that structure urban life. Although the axes of inequality we have focused on -gender, sexuality, age and race- have been sufficiently theorized from an intersectional perspective, on this occasion we've decided to show them in the light of the ethnographic methodology. To do this, we've analyzed different research works, carried out in very diverse contexts, that approach 
urbano por personas situadas en diferentes posiciones de poder y subalteridad que no responden al modelo hegemónico de ciudadano.

En estos trabajos hemos encontrado dos emociones especialmente significativas con relación a la práctica efectiva del derecho a la ciudad: el miedo y el sentirse "fuera de lugar". Ambas emociones se vinculan con el concepto de pertenencia que hemos enfatizado mediante la crítica feminista hacia la noción de derecho a la ciudad de Lefebvre.

La etnografía feminista, al fin, se nos presenta como una herramienta imprescindible para acercarnos a las dimensiones emocionales, en tanto saberes encarnados que complejizan el análisis de las desigualdades de género mediante las que se reproduce el espacio urbano. Al mismo tiempo, nos permite politizar estrategias de resistencia a menudo invisibilizadas en su vinculación con prácticas cotidianas y relacionadas con la resignificación del espacio a partir de reciprocidades, afectos y cuidados. everyday practices developed in the urban space by persons situated in different positions of power and sub-alterity that do not respond to the hegemonic model of the citizen.

In these works, we have encountered two especially significant emotions in relation to the effective practice of the right to the city: fear and feeling "out of place". Both emotions are linked to the concept off belonging that we have emphasized through our critique of the notion of right to the city in Lefebure.

Feminist ethnography, ultimately, is presented to us as an indispensable tool in approaching the emotional dimensions, as embodied knowledge that renders the analysis of the inequalities of gender by which the urban space is reproduced more complex. At the same time, it allows us to politicize strategies of resistance, frequently made invisible in their linkage to everyday practices, and related to the re-signification of space on the basis of reciprocities, affections, and care. 


\section{Referencias bibliográficas}

Aguilar, M. y Soto, P. (Coords.). (2013). Cuerpos, espacios y emociones: aproximaciones desde las ciencias sociales. Ciudad de México: Universidad Autónoma Metropolitana.

Ahmed, S. (2014). The cultural politics of emotion (2nd ed.). New York: Routledge.

Behar, R. (1996). The vulnerable observer. Boston: Beacon Press.

Bondi, L., Davidson, J., y Smith, M. (2005). Introduction: Geography's 'Emotional Turn'. En L. Bondi, M. Smith y J. Davidson (Eds.), Emotional geographies. Aldershot: Ashgate Publishing.

Buckingham, S. (2011). Análisis del derecho a la ciudad desde una perspectiva de género. Dfensor, (4), 6-12.

Cabrerizo, C., Sequera, J., y Bachiller, P. G. (2016). Entre la turistificación y los espacios de resistencia en el centro de Madrid: Algunas claves para (re)pensar la ciudad turística. Ecología Política, (52). Recuperado de https://www.ecologiapolitica.info/novaweb2/?p=6775

Enrique Rosas, R. y Sánchez López, 0. (2014). Las emociones como dispositivos para la comprensión del mundo social. Ciudad de México: Instituto Tecnológico y de Estudios Superiores de Occidente.

Fenster, T. (2005). The right to the gendered city: Different formations of belonging in everyday life. Journal of Gender Studies, 14(3), 217-231. https://doi.org/10.1080/09589230500264109
Fernández, A. M. (2011). Antropología de las emociones y teoría de los sentimientos. Versión Nueva Época, (26), 1-24.

Flam, H. (2005). Emotions map. A research agenda. En H. Flam y D. King (Eds.), Emotions and social movements (pp. 21-40). Abingdon: Routledge.

Flax, J. (1987). Postmodernism and gender relations in feminist theory. Signs, 12(4), 621-643. https://doi.org/10.1086/494359

García, C. (2013). De los no-espacios a los espacios de resistencia: aproximación etnográfica a las arquitecturas de poder en la ciudad de Granada. (Master tesis, Universidad de Granada). Recuperado de https://dspace.library.uu.nl/handle/1874/282492

García Herrera, L. M., Díaz Rodríguez, M. C., García-García, A., Armas Diaz, A., y García Hernández, J. S. (2015). Apropiación y sentido de pertenencia en el espacio público: parque Estoril (Sevilla). Revista latino-americana de geografia e gênero, 6(1), 3-13.

https://doi.org/10.5212/Rlagg.v.6.i1.0001

García Ramón, M. D. (2005). Respondiendo a un desafío pendiente en geografía: el enfoque de género visto desde España. Geographicalia, (48), 5-12.

https://doi.org/10.26754/ojs geoph/geoph.2005481324

Gregorio Gil, C. (2006). Contribuciones feministas a problemas epistemológicos de la disciplina antropológica: representación y relaciones de poder. AIBR Revista de Antropología Iberoamericana, 1(1), 22-39. https://doi.org/10.11156/aibr.010104 
Gregorio Gil, C. (2014). Traspasando las fronteras dentro-fuera: Reflexiones desde una etnografía feminista. AIBR Revista de Antropología Iberoamericana, 9(3), 297-322. https://doi.org/10.11156/aibr.090305

Gregorio Gil, C. (2015). Habitar la ciudad, construir su arquitectura: narrativas sobre el espacio urbano. En M. E. Díaz (Ed.), Arquitectura y mujeres en la historia (pp. 435-460). Madrid: Síntesis.

Gregorio Gil, C. (2019). Explorar posibilidades y potencialidades desde una etnografía feminista. Disparidades, 74(1), 1-7.

https://doi.org/10.3989/dra.2019.01.002.01

Gregorio Gil, C., Pérez Sanz, P., y Espinosa Spínola, M. (En prensa). La construcción de relaciones de confianza: tensiones y contradicciones en el campo desde una mirada feminista. En A. Álvarez, A. Arribas y G. Dietz (Eds.), Investigaciones en movimiento: etnografías colaborativas, feministas y decoloniales. Buenos Aires: CLACSO.

Gutiérrez, A. (2017). Violencia performativa contra las agresiones machistas en euskal herria. (Master tesis, Universidad de Granada). Recuperado de http://hdl.handle.net/10481/48078

Haraway, D. J. (1995). Ciencia, cybors y mujeres. La reinvención de la naturaleza. Madrid: Cátedra.

Harding, S. y O'Barr, J. (1987). Sex and scientific inquiry. Chicago: University of Chicago Press.

Harvey, D. (2008). The right to the city. New Left Review, (53), 23-39.
Harvey, D. (2012). Ciudades rebeldes: Del derecho de la ciudad a la revolución urbana. Madrid: Akal.

Jaggar, A. M. (1989). Love and knowledge: emotion in feminist epistemology. En A. M. Jaggar y S. Bordo (Eds.), Gender/body/knowledge: Feminist reconstructions of being and knowing (pp. 145171). New Jersey: Rutgers University Press.

Jasper, J. M. (2012). Las emociones y los movimientos sociales: veinte años de teoría e investigación. Revista Latinoamericana de Estudios Sobre Cuerpos, Emociones y Sociedad, 4(10), 48-68.

Le Breton, D. (2013). Por una antropología de las emociones. Revista Latinoamericana de Estudios Sobre Cuerpos, Emociones y Sociedad, 4(10), 69-79.

Lefebvre, H. (1969). El derecho a la ciudad. Barcelona: Península.

Lindón, A. (2009). La construcción socioespacial de la ciudad: el sujeto cuerpo y el sujeto sentimiento. Revista Latinoamericana de Estudios Sobre Cuerpos, Emociones y Sociedad, 1(1), 6-20.

Lindón, A. (2012). Corporalidades, emociones y espacialidades. Hacia un renovado betweenness. Revista Brasileira de Sociologia da Emoçao, 11(33), 698-723.

Lindón, A., Aguilar, M. Á., y Hiernaux, D. (Eds.). (2006). Lugares e imaginarios en la metrópolis. Ciudad de México: Anthropos.

Lugones, M. (2011). Hacia un feminismo descolonial. La Manzana de la Discordia, 6(2), 105-117. 
McDowell, L. (2000). Género, identidad y lugar. un estudio de las geografías feministas. Madrid: Cátedra.

McDowell, L. y Massey, D. (1984). A woman's place? En D. Massey y J. Allen (Eds.), Geography matters! A reader (pp. 124-147). Cambridge: Cambridge University Press. https://doi.org/10.1017/CBO9781139167833

Monk, J. y García Ramón, D. (1987). Geografía feminista: una perspectiva internacional. Documents d'Analisi Geografica, (10), 147-157.

Observatorio Metropolitano. (2014). La apuesta municipalista. Madrid: Traficantes de sueños.

Okely, J. (1992). Anthropology and autobiography. Participatory experience and embodied knowledge. En J. Okely y H. Callaway (Eds.), Anthropoloy and autobiography (pp. 1-28). London: Routledge.

Ortiz, A. (2006). Uso de los espacios públicos y construcción del sentido de pertenencia de sus habitantes en Barcelona. En A. Lindón, M. Á. Aguilar y D. Hiernaux (Eds.), Lugares e imaginarios en la metrópolis. Ciudad de México: Anthropos.

Pérez Sanz, P. (2019). Las mujeres del Cucú. Mi experiencia junto a las creadoras de una red de apoyo mutuo y cuidados. Mujeres Con Norte, (39), 20.

Quiroz, H. (2015). Urbanismo: entre la racionalidad y las emociones. Bitácora Arquitectura, (30), 4-13. https://doi.org/10.22201/fa.14058901p.2015.30.56129
Reflexiones desde la antropología en torno al cuidado. (2017). Quaders-e. 22(2).

https:/www.raco.cat/index.php/QuadernseICA/issue/ view $/ 25645$

Reguillo, R. (1998). Imaginarios globales, miedos locales. La construcción social del miedo en la ciudad. En IV Encuentro de la Asociación Latinoamericana de Investigadores de la Comunicación. Universidad Católica de Pernambuco, Recife, Brasil

Reguillo, R. (2008). Sociabilidad, inseguridad y miedos Una trilogía para pensar la ciudad contemporánea. Alteridades, 18(36), 63-74.

Rhodes, J. (2001). The voice of violence. Performative violence as protest in the Vietnam era. Connecticut: Praeger.

Rodó de Zárate, M. (2016). ¿Quién tiene derecho a la ciudad? Jóvenes lesbianas en Brasil y Cataluña desde las geografías emocionales e interseccionales. Revista Latino-americana de Geografia e Gênero, 7(1), 3-20.

https://doi.org/10.5212/Rlagg.v.7.i1.0001

Rojas, M. (2014). Geografías del miedo de mujeres trabajadoras sexuales: entre habitares y percepciones. Revista de Ciencias Sociales, (145), 61-80.

https://doi.org/10.15517/rcs.v0i145.17611

Silva, J. M., Ornat, M. J., y Chimin, A. B. (Eds.). (2017). Diálogos ibero-latino-americanos sobre geografias feministas e das sexualidades. Ponta Grossa: Todapalavra. 
Soto, P. (2013). Entre los espacios del miedo y los espacios de la violencia: discursos y prácticas sobre la corporalidad y las emociones. En M. A. Aguilar y P. Soto (Coords.), Cuerpos, espacios y emociones: aproximaciones desde las ciencias sociales (pp. 197-218). Ciudad de México: Universidad Autónoma Metropolitana.

Valentine, G. (1997). (Hetero)sexing space: Lesbian perceptions and experiences of everyday spaces. En L. McDowell y J. P. Sharp (Eds.), Space, Gender, Knowledge: Feminist Readings. London: Wiley.

Valle, T. d. (1999). Procesos de la memoria: cronotopos genéricos. La Ventana, (9), 7-43.

Valle, T. d. (2000). La organización del tiempo y del espacio: análisis feminista de la ciudad. En Invitación a la antropología urbana (pp. 53-60). Donostia: Eusko Ikaskuntza.

Viveros Vigoya, M. y Gregorio Gil, C. (2014). Presentación. Revista de Estudios Sociales, (49), $9-17$. 


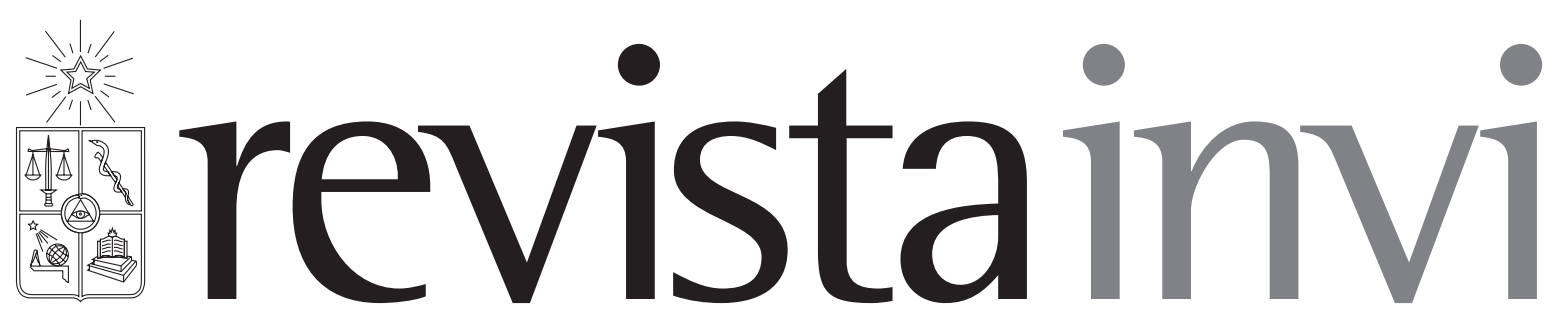

Revista INVI es una publicación periódica, editada por el Instituto de la Vivienda de la Facultad de Arquitectura y Urbanismo de la Universidad de Chile, creada en 1986 con el nombre de Boletín INVI. Es una revista académica con cobertura internacional que difunde los avances en el conocimiento sobre la vivienda, el hábitat residencial, los modos de vida y los estudios territoriales. Revista INVI publica contribuciones originales en español, inglés y portugués, privilegiando aquellas que proponen enfoques inter y multidisciplinares y que son resultado de investigaciones con financiamiento y patrocinio institucional. Se busca, con ello, contribuir al desarrollo del conocimiento científico sobre la vivienda, el hábitat y el territorio y aportar al debate público con publicaciones del más alto nivel académico.

Director: Dr. Ricardo Tapia Zarricueta, Universidad de Chile, Chile.

Editor: Dr. Luis Campos Medina, Universidad de Chile, Chile.

Editor asistente: Dr. Walter Imilan, Universidad de Chile, Chile.

Coeditora: Srta. Sandra Rivera, Universidad de Chile, Chile.

\section{COMITÉ EDITORIAL:}

Dr. Victor Delgadillo, Universidad Autónoma de la Ciudad de México, México.

Dra. María Mercedes Di Virgilio, CONICET/ IIGG, Universidad de Buenos Aires, Argentina.

Dra. Irene Molina, Uppsala Universitet, Suecia.

Dr. Gonzalo Lautaro Ojeda Ledesma, Universidad de Valparaíso, Chile.

Dra. Suzana Pasternak, Universidade de São Paulo, Brasil.

Dr. Javier Ruiz Sánchez, Universidad Politécnica de Madrid, España.

Dra. Elke Schlack Fuhrmann, Pontificia Universidad Católica de Chile, Chile.

Dr. Carlos Alberto Torres Tovar, Universidad Nacional de Colombia, Colombia.

Sitio web: http://www.revistainvi.uchile.cl/

Correo electrónico: revistainvi@uchilefau.cl

Licencia de este artículo: Creative Commons Atribución-Compartirlgual 4.0 Internacional (CC BY-SA 4.0) 